UDC: $37.01 / .09$

\title{
APPROACHES TO EDUCATIONAL QUALITY ASSESSMENT: THE EUROPEAN CONTEXT
}

\author{
Liudmyla Zagoruiko \\ Ph.D., Associate Professor of Foreign Languages Chair, \\ Pavlo Tychyna Uman State Pedagogical University, Uman, Ukraine \\ ORCID: 0000-0003-4250-3688, e-mail: hvat203@gmail.com
}

Characteristics of different approaches to the educational quality assessment in the European countries in the light of educational changes had been analyzed in the article. Contradictions had been distinguished taking into consideration the management of the education quality at the institutional level.

The processes taking place in the national and world economy lead to domination of the role of educational quality in ensuring the university competitiveness. The following fundamental processes had been considered: increasing the supply of educational services over demand; the need for the fullest satisfaction of existing and potential consumer inquiries; dominance of quality of educational services in the system of indicators of the university's competitiveness; implementation of innovative educational technologies. Based on the UNESCO programme document it was possible to define three criteria for the quality of educational activities: the quality of the staff, which is determined by the degree of academic qualification of lecturers and research staff of universities; quality of student training; the quality of the infrastructure and the "physical learning environment» of higher education institutions, covering the "whole set of conditions" of their functioning including computer networks and modern libraries.

The reasons for the formation of accreditation systems had been mentioned. It was noted that accreditation is characterized by the presence of a two-stage procedure: one organ (agency) conducts an examination and makes certain conclusions, another one (collegium or council) makes the final decision.

Strategies of internal and external quality assessment had been analysed. The author characterized two approaches to quality assurance: programme-oriented and institutional-oriented approaches.

Key words: educational quality assessment, educational quality assurance, programme-oriented approach, institutional-oriented approach, accreditation, university competitiveness, university, management of educational institutions.

У статті розглянуто особливості різних підходів до оцінки якості освіти у європейсъких крайнах з урахуВанням освітніх змін. Виокремлено протиріччя з урахуванням управління якістю освіти на інституційному рівні. Прочеси, що Відбуваються $b$ начіональній та світовій економічі, призводять до домінуВання ролі якості освіти у забезпеченні конкурентоспроможності 
уніВерситетіВ. Були розглянуті такі основні процеси: збільшення пропозиціі осВітніх послуг над попитом; необхідність повного задоволення існуючих та потенційних споживацьких запитів; домінування якості осВітніх послуг у системі показникіВ конкурентоспроможності університету; Впровадження інноваційних освітніх технологій.

Проаналізовано стратегї̈ внутрішнъої та зовнішнъої оцінки якості освіти. Автором охарактеризовано два підходи до забезпечення якості осъіти: програмно-орієнтовані та інституиійно-орієнтований.

Ключові слова: очінка якості освіти, забезпечення якості осВіти, програмно-орієнтований підхід, інституиійно-орієнтований підхід, акредитація, конкурентоспроможність уніВерситетіВ, університет, управління осВітніми закладами.

\section{Introduction}

The concept of «assessment» is associated with a system of quality assurance, which has its own history and stages of development. For the last half century, we are witnessing a «quality revolution». Its logical development is defined by the following stages: the 1960-s - the focus on the quality of goods as the main factor of market competition, the 1970-s - the shift of priority from the quality of goods to the quality of production technology, the 1980s - the transition of technology quality and production to «quality management systems», the 1990-s - the focus on quality of the person, the quality of education, the quality of intellectual resources. Besides, the wars that regularly happened in Europe have defined all spheres of production, economics, social and political institutions as national institutions, regardless of ownership, as well as limited ties between countries and determined their particular closure.

The aim of the article is to characterize different approaches to the educational quality assessment in the European countries. In European countries, for two centuries, a system of national control and responsibility for education has developed. Many of the European countries have their own traditions and experience in creating quality assurance systems (UK, Netherlands, France). There is a variety of assessment models that differ in terms of goals, methods and assessment results. Other countries (Germany, Italy, Denmark) have recently started the formation of quality assurance systems under the influence of the Bologna Process.

The creation of a control system led to standardization - the establishment of requirements, norms, rules, characteristics, both obligatory for performance and recommended, ensuring the right of the consumer to purchase goods of appropriate quality at an affordable price, as well as the right to safety and comfort of work. Objects (subjects) of standardization were production, process, services. Standardization performs the following functions:

$\checkmark$ economic, connected with the production activity of firms;

$\checkmark$ social, including methods for achieving the interests and rights of consumers;

$\checkmark$ communicative, covering the rules of the firm's activities. 
The quality of educational services is a socio-economic category, characterizing the degree of satisfaction of the consumer's expectations. Studies have shown that the quality of vocational training in a university should be considered as an educational system to satisfy the needs of the labor market in specialists of the corresponding qualification, on the one hand, and the needs of the person in obtaining competitive knowledge, on the other [1]. However, in practice, the management of the education quality at the institutional level allows to distinguish a number of the following contradictions between the:

- modern requirements of the labor market and the quality of the university education and the limited capacity to meet them on the basis of educational approaches to the management of the educational process;

- innovative processes in vocational education and the lack of a mechanism for ensuring their consistent and positive actions on the quality of educational services;

- needs of the individual in intellectual, cultural and professional development, professional identification, providing its competitive position in the labor market, and the possibility of their satisfaction in high school conditions;

- necessity of the guaranteed quality of the provided educational services and undeveloped methodological apparatus of the individual achievements;

- level of development of the theory and practice of quality implementation in various social systems and the degree of mastering these directions in the educational practice of higher education [2].

The processes taking place in the national and world economy lead to domination of the role of educational quality in ensuring the university competitiveness. Let us consider a number of the fundamental processes.

Increasing the supply of educational services over demand. This is dimensional process associated with increased competition. The numbers of universities as the educational services producers are quite large and they are compelled to courteous struggle for their consumers. In such conditions, ensuring quality satisfying consumers becomes a strategic task.

The need for the fullest satisfaction of existing and potential consumer inquiries. The quality of education is appreciated by the consumer, with the requirements and expectations of whose it should be correlated. This requires new approaches to quality planning and the development of requirements for educational services.

Dominance of quality of educational services in the system of indicators of the university's competitiveness. If the university is not able to provide a specialist with the level of quality required by the consumer, then his business, as a rule, is doomed to failure because of the low price on the market, and, as a result, it is increasingly losing its role in competition.

Implementation of innovative educational technologies. Implementation of innovative education, integrated with world educational systems, will allow starting the training of a new type of specialist who has scientific and humanitarian horizons, professionally trained to work on a chosen specialty. A young specialist must be psychologically ready to be in a dynamic environment of the changing labour market to quickly change the specialization within the framework of the received basic education, anticipate and evaluate social and environmental consequences of his activities. 
There are three criteria for the quality of educational activities. They are the following quality of:

$\checkmark$ the staff, which is determined by the degree of academic qualification of lecturers and research staff of universities. The quality of the staff and the quality of educational programs in the combination with the teaching process and scientific research, while complying with the condition of their compliance with the public demand determines the academic quality of teaching content;

$\checkmark$ the student training - in terms of diversification of education programs, the overcoming of the multi-layered gap existing between secondary and higher education, and increasing the role of mechanisms of training and youth professional orientation and motivation;

$\checkmark$ the infrastructure and the «physical learning environment» of higher education institutions, covering the «whole set of conditions» of their functioning including computer networks and modern libraries, which may be provided with adequate funding [3].

Accreditation of higher education institutions and curricula as tools to higher education quality control is widely used in the world. Accreditation involves checking higher education institutions and programs on compliance with certain criteria; as a result of accreditation the university may be either accredited or not. In different countries accreditation is carried out by state organs or independent agencies.

Under the influence of the Bologna process in the countries of Central Europe (Germany, Austria, Denmark, Norway, Sweden, etc.) the system of accreditation was issued. The reasons for the formation of accreditation systems were the following:

- expansion of autonomy and independence of state universities in determining the range of educational services, changing status in conditions of underfinancing of the education system, non-budget reception of students;

- the heterogeneity of the education system as a result of the emergence of non-state, municipal new organizational-legal forms;

- the need to preserve a single educational space (comparability of programs and mobility of students) and a high level of specialists' training.

The accreditation procedure is the final stage in the technology of assessing the quality of education. However, accreditation and evaluation are concepts that have differences. The accreditation is characterized by the presence of a two-stage procedure: one organ (agency) conducts an examination and makes certain conclusions, another one (collegium or council) makes the final decision. An important point in understanding the differences in approaches is that accreditation focuses on the accountability of the university (program) to public and state structures and is considered as a summative approach, and evaluation is oriented to development processes using the current formative approach, in the interests of the academic community. Accreditation can be institutional and specialized (programmed). Institutional accreditation reveals the institutions of education as a whole, and specialized (programmed) analyzes separate educational programs. Accreditation also can be primary and secondary. Primary (entrance examination) is conducted when new programs are started and evaluates educational resources, financial security, target settings. Secondary accreditation (subsequent examination) is carried out on the basis 
of the effectiveness of the educational process with a certain periodicity, usually in 5-6 years. The quality assurance of education is provided by autonomous, specialized organizations legally recognized at the national or regional level [4].

The assessment, unlike accreditation, allows not only checking the university's relevance to some criteria, but also to assess the degree of its competitiveness, comparing different universities with each other. On a regular basis, the assessment is carried out in more than half of the EU countries, including the UK, the Netherlands, France, Scandinavian countries. This instrument accurately takes into account the needs of development of a system of higher education as a whole, as well separate university. The assessment involves comparison and ranking of universities between themselves as well as self-assessment of universities in dynamics (the dynamics of individual indicators, progress in achieving the goals of the university).

The variety of higher education assessment systems in the 1990-s and early 2000-s can be conditionally divided into two types.

The system of assessment of higher education in those countries where there are states structures governing the development of higher education, for example, the Ministry of Education, etc. In these cases, the system of assessment is based on the priority of state bodies or structures funded by the government. At the same time self-assessment has nominal meaning and the main efforts are attached to an effective external assessment by public authorities or public bodies. Such assessment systems are often linked to government control, licensing, state accreditation, the comparison of various educational institutions, the distribution of financial resources and the impact on universities.

The system of assessment of higher education, adopted in those countries where there are no authorities of state administration of higher education or they play a smaller role. In this case, the process of self-assessments of higher educational institutions, either professional or social assessments aimed at internal analysis to improve the activities of universities.

The external assessment implies both the assessment of the university by the academic community (national or international) and other interested bodies (for example, employers). Separately we can highlight the assessment of the university by educational management authorities, in which, as a rule, the results of self-assessment and the results of the assessment by the academic community and employers are used. Various ranking systems also apply to external assessment of universities. A rating is an instrument for accumulating information and assessing the quality of universities, individual programs, teaching and research activities. Foreign ratings are based on the definition of quality, level of development of the international academic community and highlighted in the UNESCO documents. Thus, the results of the external assessment of the universities can take different forms: reports from government bodies or independent agencies, reviews, ratings of universities, etc. [2].

The self-assessment is needed, first of all, for the university itself to assess its dynamics by different parameters. However, it is also a key element in the assessment activity of the university as a whole. So, in the EU self-esteem is used in $68 \%$ countries for accreditation and $94 \%$ for the actual assessment. 
The quality assurance systems that have been created up to now in Europe (and in the world), are distinguished by relative diversity. At the same time, in some countries, the system of assessment and parallel accreditation system coexist. Under the influence of the Bologna Process and the active interaction and exchange of experience between national quality assurance systems, transformation is observed. However, all national systems have the following several general features:

$\checkmark$ the initiator of their creation was the state;

$\checkmark$ availability of autonomous quality assurance bodies;

$\checkmark$ sources of funding for procedures is the Government and/or universities;

$\checkmark$ the activities of agencies are considered as a service to the Government, the university, the society;

The goal of creating quality assurance systems is the guarantee of accountability and transparency, comparability of education at the national and international level. Specialized organizations had been created to assess the quality of education received the concept of QAA - Quality Assurance Agency. There are two approaches to quality assurance: programme-oriented and institutional-oriented approaches.

The programme-based quality assurance consists in evaluating or accrediting the quality of programmes offered by higher education institutions. The audit model is applied only rarely on the programme level. This approach is often considered as the most appropriate when a quality assurance system has just been implemented because it allows the content of programmes, which are the core business of higher education institutions, to be thoroughly examined. Other positive aspects of this approach encompass the possibility to make transversal comparison between subjects, its outcome orientation, better information about programmes offered, recognition of joint degrees, etc. On the other hand, some may have reservations about this programme based approach due, for example, to the high costs it entails, the extra bureaucracy it creates, or as mentioned in the previous section, the limited effect in improving the institution's management of teaching and learning quality. In systems where a standardised model curriculum is developed, programme-based quality assurance consists in evaluating whether the syllabus aligns with the model curriculum.

The institutional approach considers the institution as a whole, including most or sometimes even all of its operations, from educational and research activities to administrative, legal and funding aspects. The institutional approach is carried out either as quality audit, accreditation or evaluation. In most systems, its objectives are, among others, to enhance public confidence in the quality of education, training and standards of qualifications and to assess whether the internal monitoring and quality assurance arrangements are effective. This approach is often considered to allow for more flexibility in terms of structure, content and implementation of study programmes. It emphasises the autonomy and the primary responsibility of the institutions for their quality. Thus, institutional audits based on an evaluation of internal quality processes are often deemed to be a suitable method to ensure a balance between preserving autonomy and meeting the need for accountability. One of the central questions in this approach is how to address the students' and founding institutions' demands for assuring and demonstrating high quality of the programmes [5]. 


\section{Conclusions}

In general, in the scientific community and in the field of education management a long discussion about advantages and disadvantages of internal and external assessment has been provided. The main problems of the internal assessment strategy have been grounded on the fact, that universities are not always interested in a full and comprehensive description and analysis of its problems, as it can negatively influence their external image. The external assessment does not only give an objective picture, but it can serve as a «catalyst» for internal change. On the other hand, it is noted that the external assessment in terms of inadequately criteria setting may not stimulate, but restrain the development of universities. In addition, the external assessment involves significant costs, and they rarely are justified, especially if the assessment is funded at the expense of budgetary funds. It can be assumed that ideally these two methods must complement each other.

\section{References:}

1. Kuril'chenko, N. (2012). Voprosy upravlenija kachestvom obrazovanija v vuze v uslovijah perehoda na bolonskuju sistemu obuchenija. Surgut. [online] Available at: http:/molod.eduhmao.ru.

2. Maukenova, A., Nurpeisova, L., and Avgambaeva, N. (2013). Metodologicheskie podhody $k$ strategii razvitija kachestva obrazovanija [online] Available at: file://C:/Users/LUDA/Downloads/Action1379463.pdf.

3. Record of the visit of the Azerbaijan Delegation to UNESCO (2005). Programme document [online] Available at: http://unesdoc.unesco.org/images/0014/001429/142970e.pdf.

4. Filimonova, E., Voloskova, N. (2010). Sistema ocenki kachestva obrazovanija: jetapy i tendencii razvitija. Mezhdunarodnyj zhurnal jeksperimental'nogo obrazovanija. (5). Available at: http://www.expeducation. ru/ru/article/view?id $=602$

5. Amourgis, S., Costes, N., Froestad W. ets. (2009). Programme-oriented and institutional-oriented approaches to quality assurance: new developments and mixed approaches [online] Available at: http:// ww w.enqa.eu/indirme/papers-and-reports/workshop-and-seminar/ENQA\%20workshop\%20report\%209.pdf. 